\title{
IMPLEMENTASI NILAI-NILAI TASAWUF DALAM POLITIK PERSPEKTIF SOSIOLOGI
}

\author{
Eny Suhaeni \\ enysuhaeni08@gmail.com \\ (Fakultas Agama Islam Universitas Syech Yusuf Tangerang)
}

\begin{abstract}
Abstrak
Politik, sebuah kata yang di dalamnya sarat dengan makna kekerasan, manipulasi dan agitasi. Sebaliknya Tasawuf bermakna bersih, suci, santun, penuh damai dan jauh dari manipulasi. Dua terminologi ini akan terhubung dalam konteks implementasi politik atau penyelenggaran kekuasaan negara. Tasawuf salah satu jalan (tarekat) untuk memandu proses aktivitas politik dengan tujuan menciptakan tatanan masyarakat yang adil, damai dan sejahtera. Maka dimensi maha penting dari penjinakkan kekkerasan politik adalah dengan mengimplementasikan ajaran Tasawuf ke dalam aktivitas politik dalam segala aspeknya.
\end{abstract}

\section{Kata Kunci: Implementasi, tasawuf dan Politik}

\section{A. Pendahuluan}

Seringkali politik dimaknai sebagai aktivitas merebut kekuasaan dengan menghalalkan segala cara, tanpa menghiraukan etika atau akhlak. Dengan kata lain berpolitik bisa membuat seseorang jauh dari nilai-nilai agama yang menekankan tindakan apa yang seharusnya, bukan pada apa yang diinginkan. Poitik menjauhkan pelakunya dari nilai-nilai spiritual agama, sebab pokitik adalah aktivitas perebutan kekuasaan dimana para pelakunya bebas menentukan tindakan berdasarkan tujuantujuan yang ingin dicapai tanpa harus menghiraukan dimensi etika sebagai pemandu dari pencapaian tujuan.

Dalam aktivitas politik terbangun pandangan bahwa pertemuan kepentingan dalam berbagai kelompok akan selalu melahirkan konflik dan gesekan sebagai sebuah keniscayaan, sehingga diasumsikan bahwa jika agama disertakan dalam aktivitas tersebut maka bagaimana mungkin tujuan kekuasaan bisa tercapai, sebab agama meniscayakan tindakan kepada apa yang seharusnya (etika), bukan pada tujuan yang ingin dicapai dengan cara apapun (tanpa moral). Sebagaimana trend dalam wacana politik yang di gagas oleh Machiavelli setiap tindakan politik dibolehkan dengan menghalalkan segala cara demi meraih kekuasaan. Padahal jauh sebelumnya Filosof besar Aristoteles mengatakan bahwa Poitik itu justru memiliki tujuan mulia untuk mewujudkan negara yang berkeadilan dan menciptakan kesejahteraan bagi masyarakat sebuah bangsa, oleh sebab itu diperlukan cara-cara yang santun dan beretika. Bahkan dalam perspektif $\mathrm{Al}$ Ghazali, seorang filosof muslim sekaligus seorang sufi besar, mengatakan bahwa poitik dan akhlak (etika) merupakan satu kesatuan yang sinergis dalam rangka mewujudkan sistem negara yang berkeadilan, damai dan sejahtera. Keduanya merupakan saudara kembar yang tidak mungkin dipisahkan, dari keduanya akan terlihat tindakantindakan yang baik dan buruk, benar dan salah sebagaimana yang harus disesuaikan dengan keinginan masyarakat, maka politik adalah sebuah proses penyesuaian tindakan yang bertumpu pada keinginan masyarakat secara keseluruhan, dan setiap tindakan yang terkait dengan kepentingan 
masyarakat harus diadaptasikan sesuai dengan aturan-aturan moral dalam masyarakat dan harus dipertanggungjawabkan dihadapan mereka. Karena itu, berpolitik adalah juga bagian dari seni mempengaruhi dan meyakinkan melalui tata wicara dan persuasi, bukan manipulasi apalagi melakukan cara-cara tindakan kekerasan. Dalam aktivitas berpolitik, etika (akhlak) sosial merupakan bagian penting untuk dapat mewujudkan apa yang diharapkan dan diinginkan oleh masyarakat, maka segala sesuatu yang terkait dengan kehendak masyarakat memerlukan persetujuan dari masyarakat itu sendiri. Akhlak (etika) politik merupakan pengejawantahan dari nilainilai kebenaran, kejujuran, keadilan dan tanggung jawab dalam realitas kehidupan.

Untuk itu tindakan-tindakan politik diupayakan dengan mengkonsepsi, menggali dan mengelaborasi secara lebih dalam pandangan-pandangan etika /moral (akhlak) yang menuntun setiap orang pada tindakan-tindakan yang benar menurut hukum tata nilai kolektif. Fakta memperlihatkan bahwa tidak sedikit tindakan-tindakan politik yang menghalalkan segala cara dalam memperoleh kekuasaan atau mempertahankan kekuasaan, lalu mengabaikan nilainilai keadaban yang di junjung tinggi oleh masyarakat secara kolektif. Untuk itulah etika/moral (akhlak) dalam politik menjadi sangat penting sebagai pemandu tindakan untuk tercapainya tujuan bersama.

\section{B. Politik Dan Tasawuf}

Dalam politik seringkali berlaku adagium bahwa "dalam politik tidak ada lawan dan kawan sejati, yang ada dan abadi dalam politik adalah kepentingan". Ketika kepentingannya sama, mereka berkawan, namun ketika kepentingannya berbeda mereka menjadi lawan. Jika poitik dipandang seperti adagium ini, maka politik adalah sesuatu yang kotor, gersang, jauh dari nilai-nilai agama. Dengan begitu tak ada lagi tempat bagi para ulama, cendekiawan, orang-orang shalih untuk memasukinya, sebab area politik adalah tempat yang sangat berbahaya bagi keberlangsungan agama karena penuh dengan intrik dan tindakan a-moral, asusila dan lain-lain.

Dalam Islam politik adalah bagian dari urusan mu'amalah dimana seluruh aspek kehidupan baik dari mulai urusan politik, sosial, ekonomi, budaya, pendidikan, dan agama harus diatur dan diformulasikan berdasarkan kaidah atau nilai-nilai agama Islam. ajaran Islam tidak mengenal pemisahan urusan dalam segala aspek kehidupan. Ajaran Islam justru mengintegrasikan urusan-urusan tersebut ke dalam urusan yang integratif dalam satu ruang dan waktu, yakni Islam memadukan ajaran-ajarannya dalam seluruh aspek kehidupan dalam dua ruang yang integral yakni ruang dunia dan akhirat. Politik adalah sebuah ikhtiar untuk membangun keadaban manusia yang tujuannya adalah membuat manusia sampai pada hakikat kemanusiaannya dan menemukan penciptanya. Maka bagi umat Islam wajib hukumnya melakukan ikhtiar itu, supaya manusia sebagai khalifah sanggup mempertanggungjawabkan dirinya sebagai khalifah dihadapan Tuhannya kelak dikemudian hari, sehingga bagi umat Islam ikhtiar untuk menemukan cara hidup yang “rahmatan lil'alamin' adalah sebuah keniscayaan yang harus ditemukan dan menjadi tuntutan dalam segala aspek kehidupannya. Karena itu, ajaran Islam bersifat universal dan tuntutannya dalam aspek politik harus tetap dan relevan dalam setiap zaman. Dalam segala aspek kehidupan, akhlak Islam harus menjadi rujukan atau pedoman ajaran Islam menjadi nafas dalam setiap gerakan atau aktivitas kehidupan manusia muslim. Kecurangan, penipuan, suap, dusta, korup, dan yang sejenisnya adalah penzaliman 
yang dilarang keras dalam ajaran Islam. setiap muslim harus mempraktekkan nilainilai etika/akhlak mulia dalam seluruh sepak terjang kehidupannya. Tak ada dalam kamus ajaran Islam bahwa dalam berpolitik seseorang dihalalkan menempuh cara-cara yang tidak terpuji dan tidak sesuai dengan kaidah-kaidah Islam.

Tasawuf adalah salah satu dimensi penting dalam ajaran Islam yang mencakup inti atau substansi amaliah dari ajaran Islam. Tasawuf membawa manusia kepada hakikat jalan akhir menemui Allah. Dimensi penting dari ajaran tasawuf adalah proses pengosongan dan pensucian jiwa dari sikap, tindakan atau tingkah laku yang tercela. Orientasi ajaran tasawuf adalah berusaha menjauhkan sikap hidup bermewah-mewah (hedonis), pragmatis, materialis dan sikap hidup lainnya yang akan membawa keburukan tidak saja bagi dirinya namun juga bagi orang lain.

Dalam persepektif politik yang adagiumnya seringkali tertumpu pada proses menghalalkan sebgala cara, maka tasawuf dianggap ajaran yang sanggup menjinakkan sikap dan tindakan politik yang destruktif, koruptif, manipulatif dan sikap-sikap lainnya yang cenderung mementingkan diri sendiri. Tasawuf bisa dihadirkan sebagai tarekah (jalan) menuju pembersihan atau pensuciandari segala tindakan tercela dalam segala aspek kehidupan.

\section{Pengertian Politik}

Apakah poitik itu sebenarnya? Pengertian politik secara etimologi berasal dari bahasa Arab yakni kata Siyasyah yang berarti mengatur, mengendalikan, mengurus, atau membuat keputusan, memerintah dan memimpin, yang selanjutnya kata ini kemudian diterjemahkna menjadi Siasat, atau dalam bahasa Inggrisnya disebut Politics. Politik bermakna cerdik dan bijaksana, yang dalam wacana sehari-hari bermakna sebagai suatu cara yang dipakai untuk mewujudkan tujuan, tetapi para ahli politik mengakui bahwa sangat sulit memberikan definisi politik. ${ }^{1}$

Secara istilah pengertian Siyasasah menurut Ibnu Al Qayyim, adalah segala perbuatan yang membawa manusia lebih dekat kepada kemaslahatan dan lebih jauh kepada kemafsadatan, sekalipun Rasulullah tidak menetapkannya dan (bahkan) Allah tidak menentukannya. Rasulullah SAW sendiri menggunakan kata politik (Siyasah) dalam sabdanya: Adalah bani Israil, mereka diurusi (siyasah) urusannya oleh pra nabi(tasusuhumul anbiyya. Ketika seorang Nabi wafat, Nabi yang lain datang menggantinya, tidak ada nabi setelahku, namun akan ada banyak para khalifah (HR Bukhari dan Muslim).

Sehingga jelas bahwa poitik atau siyasah itu bermakna mengurusi urusan masyarakat, bahkan Rasulullah bersabda: "siapa saja yang bangun dipagi hari dan dia hanya memperhatikan urusan dunianya, maka orng tersebut tidak punya makna papun disisi Allah, dan barangsiapa tidak memperhatikan urusan kaum muslimin, maka dia tidak termasuk glongan mereka(yaitu kaum muslim). (HR Thabrani).

Lebih lanjut Ibnu Taimiyyah dalam kitab Siyasah as-Syar'iyyah hal 168 menjelaskan: "wajib diketahui bahwa mengurusi dan melayani kepentingan manusia merupakan kewajiban terbesar agama diman agama dan dunia tidk bisa tegak tanpanya. Sungguh bani adam tidak akan lengkap kemaslahtannya dalam agama tanpa adanya jama'ah dan tidak ada jama'ah tanpa adanya kepemimpinan, Nabi bersabda: "jika keluar tiga orang untuk bersfar maka hendaklah mereka mengangkat salah satunya sebagai pemimpin (HR Abu Daud). Nabi

${ }^{1}$ DR. Inu Kencana syafi'i, MSi, Pengantar Ilmu Politik, Penerbit Rineka Cipta, Jakarta, 2010. 
mewajibkan umatnya mengangkat pemimpin bahkan dalam kelompok kecil sekalipun dalam rangka melakukan amar ma;ruf nahyi munkar, melksanakan jihad, menegakkan keadilan, menunajikan haji, mengumpilkan zakat, mengadakan shalat ied, menolong orang yang di zhalimi dan menerpkkan hukum hudud.

Pada dasarnya politik mempunyai ruang lingkup negara, karena teori politik menyelidiki negara sebagai bagian dari lembaga politik yang mempengaruhi kehidupan masyarakat, jadi negara dalam keadaan bergerak. selain itu teori politik juga menyelidiki ide-ide, asas-asas, dasar negara, sejarah terbentuknya negara, hakikat adanya negara, tujuan negara, disamping menganalisis dan memahami kelompok-kelompok kepentingan, kelompok elite, kelompok penekanm pendapat umum, penataan partai poitik, partisipasi masyarakat dalam pemilihan umum, dan lain sebagainya. Asal mula kata politik itu sendiri berasal dari kata polis yang artinya negara kota,dengan demikian politik berarti terkait dengan adanya hubungan khusus antara manusia yang hidup bersama, maka dalam hubungan tersebut muncul norma, aturan, kesepakatan, prilku penguasa, legalitas kekuasaan, dan sebagainya. namun politik juga mengandung makna kebijaksanaan, kekuatan, kekuasaan pemerintah, pengaturan konflik yang menjadi konsesnsus nasional, dan lalu kekuatan massa rakyat.

Ada banyak pendapat tentang teoriteori politik yang deikemukakan oleh para ahli, diantaranya menurut:

a. Aristoteles: Politik adalah usaha yang ditempuh warga negara untuk mewujudkan kebaikan bersama.

b. Poitik mengandung makna suatu aktivitas mengenai Bansa atau negara yang memiliki tujuan dalam membuat, memepertahankan, mengamandemen berbagai peraturan yang umum yang mengatur keberlangsungannya sehingga tidak terlepas dari gejala konflik dn kerjasama. (Andrew Heywood).

c. Roger Soltau: Poitik adalah sebuah ilmu yang menganalisis tentang negara yang didalamnya ada tujuan dan melaksanakan tujuan tersebut, termasuk menganalisis hubungan antara negara dan warga negara serta hubungan dengan negara lain.

d. Ramlan Surbakti: Politik adalah sebuah proses interaksi antara pemerintah dan masyarakat yang memiliki tujuan menentukan kebaikan terhadap suatu wilayah dan masyarakat yang menempati wilayah tersebut.

e. Politik adalah ilmu dan seni untuk meraih kekuasaan secara konstitusional maupun non konstitusional.

Dengan demikian pengertian politik secara istilah (terminologi) mengandung makna sebuah aktivitas yang bersifat mengolah, membina, mengatur, menduduki, mempertahankan, membuat, menyesuaikan, melaksankan, menentukan segala hal yang terkait dengan masyarakat, negara-bangsa demi kemaslahatan bersama.

\section{Pengertian Tasawuf}

Terdapat beberapa definisi Tasawuf secara etimologi (heurmeuneutik/bahasa)

a. Tasawuf berasal dari kata "Shuf", yang berarti wol kasar, sebagai lambang kesederhanaan bagi orang-orang sufi dan merupakan reaksi terhadap kehidupan mewah yang dilakukan dan dinikmati oleh para elite penguasa. Kaum sufi yang mengenakan baju wol kasar ini beusaha memberikan contoh keteladnan Rasulullah SAW sebagai pemimpin dengan sikap hidup sangat sederhana meski beliau sebagai seorang kepala Negara.

b. Tasawuf berasal dari makna yang di konotasikan dengan Ahl-Suffah, yakni 
orang-orang yang tinggal di suatu kamar disamping mesjid Nabi di Madinah. Mereka adalah orang-orang miskin yang kehilangan harta benda karena mengikuti hijrah nabi dari Mekkah ke Madinah. Mereka tidur diatas batu dengan pelana (Assuffah) sebagai bantal. Mereka adalah para pejuang Fisabilillah dan selalu mendekatkan diri kepada Allah SWT.

c. Tasawuf berasal dari kata "Shopos" yang berarti 'Hikmah', artinya mereka orang-orang ahli hikmah adalah yang selalu mensucikan diri untuk mendekatkan diri kepada Allah. Mereka berpandangan bahwa Allah maha suci maka haruslah didekati dengan jiwa yang suci.

d. Tasawuf terkait dengan kata Assiffah (Sifat) karena para sufi sangat mementingkan sifat-sifat terpuji dan menjauhi sifat-sifat tercela.

Secara terminologi Tasawuf memiliki pengertian sebuah aktivitas yang menggerakkan jiwa untuk memasuki kehidupan rohani dan menjauhkan diri dari sikap hidup penuh kebendaan. Beberapa definisi dikemukakan antara lain: Tasawuf bermakna $A l$ Bidayah; Manusia karena hakikat fitrahnya cenderung memiliki hati yang bersih dan suci. Setiap manusia sesuai fitrahnya ingin menjauh dari segala bentuk keburukan dan penyakit bathin serta bebas dari segala bentuk penguasaan syahwat, sehingga mereka (orang-orang suci dan bersih hati) ini selalu berada di barisan pertama dan mendapat derajat yang tinggi serta kebenaran. Meraka yang bersih hatinya tidak pernah ditimpa suatu kelemahan, tidak menyusahkan dirinya dari segala permintaan dalam bentuk pemenuhan nafsu syahwat, dan tidak pernah menyusahkan dirinya dari ketiadaan harta, kekuasaan atau lainnya yang bersifat duniawi atau kebendaan.

Seseorang yang masuk dalam area dunia sufistik adalah mereka yang terus menerus membersihkan hatinya dari penyakit bathin dan terus menerus berada dalam pengembaran nilai-nilai spriritual untuk menemukan hakikat dirinya dan Tuhannya. Sikap menentang hal-hal yang bersifat duniawi adalah energi bagi kehidupannya yang tak lekang dan kering, sebab kebersihan jiwa baginya adalah representasi dari kesucian untuk sampai kepada Allah. $^{2}$

Tasawuf bertujuan memperoleh suatu hubungan khusus langsung dari Tuhan. Hubungan dimaksud mempunyai makan dengan penuh kesadaran bahwa manusia hakikatnya sedang berada di hadirat Tuhan. Kesadarn tersebuat akan menuju bentuk komunikasi intesif antara roh manusia dan Tuhan. ${ }^{3}$

Tasawuf merupakan aspek esoteris dari ajaran Islam, sebab Tasawuf adalah jantung atau urat nadi pelaksanaan ajaranajaran Islam. tasawuf inilah merupakan kunci kesempurnaan amaliah dari semua ajaran Islam. oleh sebab itu Tasawuf merupakan jalan spiritual dan dimensi bathin seorang manusia. Abul A'la Almaududi menyebutkannya sebagai :the spirit of conduct. ${ }^{4}$ sebagai proses pembersihan atau pengosongan menuju pensucian jiwa dari kehendak dan tindakan yang tercela menuju tindakan yang terpuji.

\section{Krisis Spiritual Dalam Masyarakat Modern}

Masyarakat modern adalah sebuah komunitas yang hidup bersama dalam suatu wilayah tertentu dan terikat secara emosional dan memiliki kesepakatan untuk mencapai suatu tujuan bersama. Dan berada dalam situasi sistem kehidupan

\footnotetext{
${ }^{2}$ Drs. A Bachrun, MA.d dkk, Filsafat Tasawuf, CV Pustaka Setia, Bandung, 2010

${ }^{3}$ DR. Rosihan Anwar, M.Ag. Akhlaq Tasawuf, CV. Pustaka Setia, Bandung, 2010

${ }^{4}$ Drs. Bachrun dkk, Filsafat Tasawuf, Bandung, Pustaka Setia,
} 
yang bersifat mutakhir. ${ }^{5}$ Deliar Noer menyebutkan ciri-ciri masyarakat modern sebagai berikut :

1. Bersifat rasional, yakni lebih mengutamakan pendapat akal pikiran, ketimbang emosional, sebelum melakukan pekerjaan selalu dipertimbangkan untung ruginya, jika pekerjaan tersebut menguntungkan secara logika maka akan dilakukan.

2. Berfikir visioner, lebih jauh untuk masa depan, yakni selalu melihat sesuatu lebih jauh, tidak sekedar memikirkan masalah yang bersifat sesaat, namun selalu dilihat dampak sosial secara lebih jauh.

3. Sangat menghargai waktu, selalu melihat bahwa waktu merupakan sesuatu yang sangat berharga dn perlu dimanfaatkan sebaik-baiknya.

4. Bersikap terbuka, yakni mau menerima saran, masukan, baik berupa kritik, gagasan dan perbaikan darimanapun datangnya.

5. Berfikir objektif, melihat segala sesuatu dari sudut fungsi dn kegunaannya bagi masyarakat. $^{6}$

Menurut Alfin Toffler dalam bukunya The Tird Wave" masyarakat terbagi kedalam tiga gelombang peradaban manusia, pertama masyarakat pertanian, (agricultural society), kedua, masyarakat Industri (iIndustrial Society), dan ketiga masyarakat Informasi (Informatical Society). Ketiga model masyarakat tersebut memiliki ciri-ciri sebagai berikut: masyarakat pertanian mendasarkan sumber-sumber ekonominya pada tanah dan sumber daya alam . mereka memiliki sawahn ladang, kebun, dan lahan pertanian yang luas sebagai ciri orang kaya raya di pedesaaan. Sistem informasi yang mereka

\footnotetext{
${ }^{5}$ DR. Rosihan Anwar, Akhlak tasawuf, Bandung, Pustaka Setia, 2010

${ }^{6}$ Deliar Noer, Pembangunan di Indonesia, (Jakarta, 1987, hal 24)
}

gunakan berupa lisan atau dari mulut ke mulut. Tekhnologinya sangat sederhana, menganut sistem keluarga batih, menetap di suatu wilayah, bersifat guyub (gotong royong), ikatan emosional sangat kuat, berfikir tradisional dan mistikal.

Pada masyarakat dengan modelm kedua yakni masyarakat industri, cara-cara hidupnya berbeda dari model pertama. Masyarakat Industri menggunakan modal dasar dalam pencarian sumber ekonominya berdasarkan industri dengan tekhnologi mesin. Dimana sumber bahan mental di olah menjadi bahan siap konsumsi dan distribusi. Tekhnologi yang digunakan merupakan tekhnologi tinggi dengan skala besar dan massif, hemat tenaga kerja. Sistem informasi menggunakan media yang dibaca dan mudah disimpn oleh siapa saja, bekerja secara efektif dan sistem kekeluargaan bersifat individual. Dan tidak memiliki keluarga besar sebagaimana dalam masyarakat pertanian.

Selanjutnya pada corak masyarakat ketiga yakni masyarakat informasi (Informatical Society), sebagian menyebut abad elektronik atau abad millenial. Pada pola-pola hidup masyarakat millenial ini, dasar-dasar ekonomi bersumber pada kepemilikan alat-alat media jejaring sosial, dan penguasaan atas jejaring sosial menimbulkan penguasaan atas susmbersumber ekonomi. Lingkungan sosial yang terbangun dalam model masyarakat millenial ini sangat rapuh dan mudah berubah. Era ini lebih banyak dikenal dengan istilah masyarakat maya (Cyber community). Kecenderungan semua prilaku pada model masyarakat ini lebih bersifat maya tapi nyata. Masyarakat seperti ini berada pada rumah-rumah maya dalam melakukan segala aktivitasnya.

Pada akhirnya, perubahan yang terjadi pada masyarakat dengan sistem informasi paling mutakhir ini adalah longgarnya nilai-nilai sosial, budaya, politik, ekonomi dan bahkan agama 
menjadi sangat mudah berubah. Hal ini disebabkan karena mudahnya setiap individu mengakses informasi dalam hitungan detik. Sehingga setiap orang memiliki kebebasan menyerap informasi apa saja didalam jejaring media sesuai dengan jejaring apa yang mereka inginkan dengan cepat. Facebook, instagram, watshsap, twitter dan berbagai media cepat lainnya membanjiri masyarakat dengan model ini.

Perkembangan dan perubahan sangat cepat seperti itu juga berdampak pada pola-pola cara berinteraksi dan cara menyerap nilai-nilai yang serba cepat. Masyarakat cyber (maya) disuguhkan berbagai pola-pola hidup yang serba cepat dan mutakhir, nilai-nilai spiriutual dalam konteks prilaku ekonomi, politik, sosial, budaya, agama dll menjadi sangat cair. Manusia banyak yang kehilangan energi spiritual dalam berbagai dimensi kehidupannya. Revolusi industri dan revolusi informasi merubah mindset masyarakat menjadi masyarakat yang gampang berubah dengan pola-pola interaksi yang dinamis dan lentur namun kering energi spiritual.

Bahkan dalam dunia politik, masyarakat millenial cenderung mudah terprovokasi dengan informasi yang bersifat hoax atau bohong. Dunia media sosial menjadi ajang saling hujat, saling memaki antara kelompok satu dengan kelompok lainnya, antara golongan satu dengan golobgan lain, antara pendukung salah satu kandidat pemimpin dengan pendukung kandidat lawan. Negara secara umum mengalami disintegrasi tidak saja secara politik, namun juga dalam semua dimensi kehidupan.

Demikian juga dalam transaksi ekonomi, wajah ekonomi yang mengemuka adalah wajah yang bernuansa ekonomi liberalis karena sistem transaksi lebih banyak dilakukan lewat media sosial yang bersifat maya dan hanya membutuhkan rasa percaya (trust) yang tinggi, sebab yang dilakukan adalah transaksi tanpa harus berhadapan langsung.

\section{Mentasawufkan Politik}

Menghubungkan tasawuf dan politik setidaknya membantu meluruskan tujuan hidup bermasyarakat dan berbangsa. Tasawuf merupakan jalan (tarekat) menuju kemanunggalan Tuhan. Politik adalah salah satu sarana menuju jalan itu. Maka antara tasawuf dan politik terbuka jalan untuk sampai pada tujuan. Dan tujuan yang dimaksud adalah manusia sebagai makhluq dan khaliq harus sampai pada sebuah pertemuan Rabbnya dengan selamat. Artinya hakikat keselamatan adalah perjumpaan ruh manusia sebagai makhluk dan ruh Tuhan sebagai Khaliq. Antara khaliq dan makhluk bisa bersatu dalam kemanunggalan (kembali kepada hakikat ruh Tuhannya) harus dengan melalui proses pembersihan dan pensucian jiwa. Sebab sang Khaliq sebagai tempat penyatuan harus di dhampiri dengan pendekatan pengosongan diri dari keinginan pemenuhan nafsu syahwat yang justru cenderung menjauhkan dirinya dari mendekat kepada Tuhan.

Dalam konteks politik, tasawuf bisa dipakai sebagai jalan untuk mensucikan diri dari perbuatan-perbuatan tercela. Politik kerapkali menyebabkan manusia semakin jauh dari Tuhan, sebab dalam aktivitas politik kecenderungan para politisi adalah melakukan aksi-aksinya tanpa didasari nilai-nilai agama. Secara umum berlaku pendapat bahwa agama tidak penting di bawa dalam arena politik, karena agama adalah wilayah privat dan politik wilayah publik. Jadi antara urusan privat dan publik tidak menemu jalan.

Dalam Islam, Al Qur'an berkali-kali menyinggung soal peran manusia di dalam tugasnya sebagai khalifah (pemimpin) di bumi. Watak seorang khalifah (pemimpin) yang digambarkan al-Qur'an haruslah 
seorang yang memiliki kemampuan memaksimalkan akal pikiran, memiliki intuisi yang kuat dan terpuji, memiliki sikap mental maupun intelektual untuk melakukan taghyir ke arah yang baik dan mulia. Manusia seperti ini oleh al Qur'an di sebut sebagai Insan Kamil (manusia sempurna). Menurut Eny Suhaeni sebagai makhluk sosial, manusia tidak dapat hidup sendirian, karena ada sekian kebutuhan yang tidak mampu ditangani oleh dirinya sendiri, hal tersebut membutuhkan orang lain'. Hidup manusia bagaikan lalu lintas, dengan saling ketergantungan satu sama lain, namun masing-masing memiliki harapan berjalan dengan selamat sekaligus sampai kepada tujuan. ${ }^{7}$

Para ahli Tasawuf bersepakat bahwa insan kamil adalah gambaran manusia yang memiliki nilai-nilai luhur dan suci di dalam seluruh aspek perbuatannya. Kata al insan disebut sebanyak 65 kali dalam al Qur'an dan digunakan untuk menyatakan manusia dalam lapangan kegiatan yang amat luas. Musa Al'asy'ari mnyebutkan lapangan kegiatan insan kamil setidaknya ada 6 bidang : Pertama : bahwa manusia mendapatkan pelajaran dari Tuhan tentang apa yang tidak diketahuinya. (QS: Al- 'Alaq 96: 1-5). Kedua : manusia mempunyai musuh yang nyata yaitu setan (QS:12:5). Ketiga, manusia memikul amanat dari Tuhan. (QS:33:72). Keempat, manusia harus menggunakan waktu dengan baik . (QS:105:1-3). Kelima, manusia hanya akan dapat bagian dari apa yang telah diusahakannya. (QS;53:39). Keenam, Manusia memiliki keterikatan dengan moral atau etika . (QS:29:8). ${ }^{8}$

\footnotetext{
${ }^{7}$ Eny Suhaeni, Islam dan Pluralitas Agama di Indonesia, Jurnal ISLAMIKA, Vol. 17, Desember. 2017

${ }^{8}$ Prof. Dr. H. Abuddinata, Akhlaq Tasawuf dan Karakter Mulia, Jakarta, raja Grapindo Persada, h. 225
}

Manusia sebagaimana Ibnu Khaldun menyebutkan. ${ }^{9} \quad$ Memiliki pancaindera (anggota tubuh), akal pikiran, dan hati sanubari. Ketiga potensi ini haruslah bersih, sehat dan berdaya guna serta dapat bekerjasama secara harmonis. Pemberdayaan ketiga potensi ini dalam al Qur'an tertera dalam QS:67:23. Pada ayat tersebut terdapat kata Al'Afidah yang bermakna hati (qalbu). Al Raqib Al Asfahani, dalam Kamus A-1 Qur'an, mengatakan bahwa kata $A l$ Af'idah merupakan jamak dari kata $F u$ 'ad yang artinya sama dengan $\mathrm{Al}$ Qlb (hati), namun al fu'ad lebih menunjukkan pada bekerjanya dalam menimbang-nimbang masalah secara jernih. Karenanya $A l$ Fu'ad lebih cocok disebut hati kecil (hati nur'ani) yang tak pernah berbohong. Sedangkan $A l$ Qlb secara harfiah bermakna bolak balik dan ini menunjukkan pada bekerjanya hati yang tidak tetap. Terkadang suka, terkadang benci, terkadang kasihanm, terkadang kejam, intimidatif dan lainlainnya. Karenanya ia bisa diperdaya setan.

Tasawuf dalam konteks tulisan ini terkait dengan proses pembersihan, pensucian, penghindaran $\mathrm{Al} \mathrm{Fu}$ 'ad (hati sanubari), agar ia tetap jernih, suci, bersih, bening. Dengan demikian dia dapat memancarkan akhlaq yang mulia. Dan substansi inilah yang dimaksud dalam hubungan antara Tasawuf dan politik, sehingga dalam konteks pengembangan masyarakat bangsa akan terbangun wajah negara yang penuh dengan kedamaian, kesejahteraan lahir dan bathin.

Seorang politisi yang berakhlak dengan akhlak tasawuf dalam tindakannya politiknya akan selalu dipandu oleh hati sanubarinya yang paling dalam (al fu'ad), upaya-upaya politik yang dilakukannya akan mendorong dirinya untuk selalu bersikap menghindari dirinya dari perbuatan-perbuatan atau tindakan yang

${ }^{9}$ Ibid h. 153 
manipulatif, otoriter, zhalim dan mau menang sendiri. Sebaliknya, ia akan melakukan hal-hal terpuji disebabkan tanggung jawab terhadap masyarakatnya, bangsanya dan terpenting kepada Tuhan. Dan paradigma seperti ini akan menghantarkan dirinya menuju kepada pertalian dengan Allah. Ia selalu berupaya mengontrol dan menyadarkan dirinya dalam setiap tindakan politiknya dengan menggunakan sudut pandang bahwa segala sesuatu keputusan, perubahan, pembinaaan, pengaturan akan terhubung selalu dengan Tuhan.

Dengan demikian, berdasarkan beberap formulasi ajaran Islam yang sudah diuraikan di atas, kita bisa melihat bahwa Islam dengan sumber ajaran Al Qur'an telah memotret manusia dalam sosoknya yang benar-benar utuh (insan kamil) dan menyeluruh. Seluruh isi dan aspek dari kehidupan manusia dipotret dengan cara yang amat akurat yakni seorang sosok manusia yang berdaya adalah dia yang penuh dedikasi, dengan kekuatan jasmani dan rohaninya, kemampuan intelektual, emosional, intuisi dan aspek-aspek lainnya yang sanggup dikembangkan untuk kepentingan masyarakat dan bangsanya.

Dalam percaturan realitas politik justru banyak sekali orang berpandangan bahwa politik tak terhubung sama sekali dengan pemaknaan agama. Pandangan inilah yang sering menyebabkan banyak para aktivis politik kehilangan energi spiritual agamanya dan tidak memiliki kemampuan mendobrak tatanan masyarakat dan bangsanya ke arah yang lebih baik. Yang terjadi adalah makin merajalelanya pergesekan yang mengarah kepada konflik dan berujung kekerasan, pertumpahan darah, saling membunuh dan saling menghancurkan satu sama lain. Lalu sikap hidup Koruptif dianggap sebagai efek dari munculnya masyarakat materialistis, pragmatis dan manupulatif. Ironisnya masyarakat secara umum melakukan pembiaran terhadap situasi tersebut dengan anggapan bahwa jika ikut terlibat dalam urusan konflik politik akan melahirkan kerugian yang besar dalam dirinya. Maka muncullah sikap individualisme, egoisme ditambah lagi setiap orang merasa dalam keadaan benar tanpa melibatkan dirinya dalam politik. padahal justru politik diperlukan untuk mengatur dan menegakkan regulasi yang lebih berwawasan dan berkeadaban. Pada akhirnya politik dipandang sebagai sesuatu yang "haram" untuk diterjuni. Karena di dalamnya penuh dengan intrik dan melulu saling berkonflik. Tasawuf salah satu ajaran tarekat (Jaan) untuk melatih (Riyadhah) manusia menemukan hakikat dirinya dan Tuhannya. dan menemukan kesadaran baru bahwa keseluruhan aspek kehidupannya adalah sebagai bagian dari diutusnya dirinya sebagai khalifah fil ardly dengan terus menerus memberdayakan potensi-potensi besar dalam dirinya.

Terakhir, tasawuf dan politik adalah dua hal penting yang harus diaplikasikan dalam konteks pengembangan peradaban manusia. Tanpa politik manusia tidak mungkin sanggup menegakkan daulat kekuasaan masyarakat dan negaranya. Sikap dan tindakan penzhaliman, anarkhisme dalam penegakkan kekuasaan (bac: negara-bangsa) membutuhkan kesdaran yang amat tinggi, bhwa menjadi pemimpin (khalifah) adalah sala satu tanggung jawab besar yang dibebankan kepada umat manusia, alhasil disetujui atau tidak hanya tinggal bagaimana manusia menjalani tanggungjawab itu. Masyarakatbangsa sangat membutuhkan para penegaknya yang memiliki integritas akhlak/moral yang tinggi, maka ajaran Tasawuf adalah suatu sarana untukm melatih ke arah jalan itu hingga sampai ke hadadapan-Nya. 


\section{E. Penutup}

Politik adalah sebuah proses penyesuaian tindakan yang bertumpu pada keinginan masyarakat secara keseluruhan, dan setiap tindakan yang terkait dengan kepentingan masyarakat harus diadaptasikan sesuai dengan aturan-aturan moral dalam masyarakat dan harus dipertanggungjawabkan, berpolitik adalah juga bagian dari seni mempengaruhi dan meyakinkan melalui tata wicara dan persuasi, bukan manipulasi apalagi melakukan cara-cara tindakan kekerasan. Politik, sebuah kata yang di dalamnya sarat dengan makna kekerasan, manipulasi dan agitasi. Sebaliknya Tasawuf bermakna bersih, suci, santun, penuh damai dan jauh dari manipulasi. Dua terminologi ini akan terhubung dalam konteks implementasi politik atau penyelenggaran kekuasaan negara. Tasawuf salah satu jalan (tarekat) untuk memandu proses aktivitas politik dengan tujuan menciptakan tatanan masyarakat yang adil, damai dan sejahtera. Maka dimensi maha penting dari penjinakkan kekkerasan politik adalah dengan mengimplementasikan ajaran Tasawuf ke dalam aktivitas politik dalam segala aspeknya.

\section{DAFTAR PUSTAKA}

Abuddinata, Akhlak Tasawuf, Jakarta, PT.Grafindo Persada, 2017

A. Bachrun Rif'i. dkk, Filsafat Tasawuf, Bandung: Pustaka Setia, 2010
Abuddinata, Akhlak Tasawuf, Bandung, Pustaka Setia,1996

Ali Harb. Nalar Kritis, Jogyakarta, IRCisod, 2012

Carlton Clymer Rodee dkk, Pengantar Ilmu Politik,Depok, Rajawali Pers, 2013 cet ke-13

Hendra, Nurtjahjo, Filsafat demokrasi, Jakarta, PT Bumi Aksara, 2006

Haryatmoko, Etika Politik dan Kekuasaan, Jakarta, Penerbit Buku Kompas, 2003

Inu Kencana Syafi'ie. Ilmu Politik,Jakarta, Rhineka Cipta, 2010-03-27

Jurnal ISLAMIKA, Fakultas Agama Islam UNIS, Vol . 17, 17 Desember 2017

Jurnal ISLAMIKA, Fakultas Agama Islam UNIS, Vol . 17, 17 Desember 2017

Murray Print dkk, Civic Education for Civil Society, London, ASEAN Academic Press, 1998

Nasaruddin Umar, Islam Fungsional, Jakarta, PT Gramedia, 2014

Rosihan Anwar, Akhlaq Tasawuf, Bandung, Pustaka Setia, 2010

Tiar Anwar Bachtiar, Pertarungan Pemikiran Islam di Indonesia, Jakarta, Pustaka Alkautsar, 2017

Zaim Saidi, Ilusi Demokrasi, Kritik dan Otokritik Islam, Jakarta, Republika, 2007 
Implementasi Nilai-Nilai Tasawuf dalam Politik Perspektif Sosiologi 